\title{
Acute aortic dissection in sepsis with \\ Staphylococcus bacteraemia
}

Saad Rehan, ${ }^{1}$ Francis $\mathrm{Ha},{ }^{1}$ A K M Nizam Uddin (10) ${ }^{2,3}$

${ }^{1}$ Medicine, Central Gippsland Health Service, Sale, Victoria, Australia

${ }^{2}$ Medicine Department, Central Gippsland Health Service, Sale, Victoria, Australia

${ }^{3}$ Monash Lung \& Sleep, Monash Health, Clayton, Victoria, Australia

Correspondence to Dr A K M Nizam Uddin; akmnizam@gmail.com

Accepted 22 June 2021
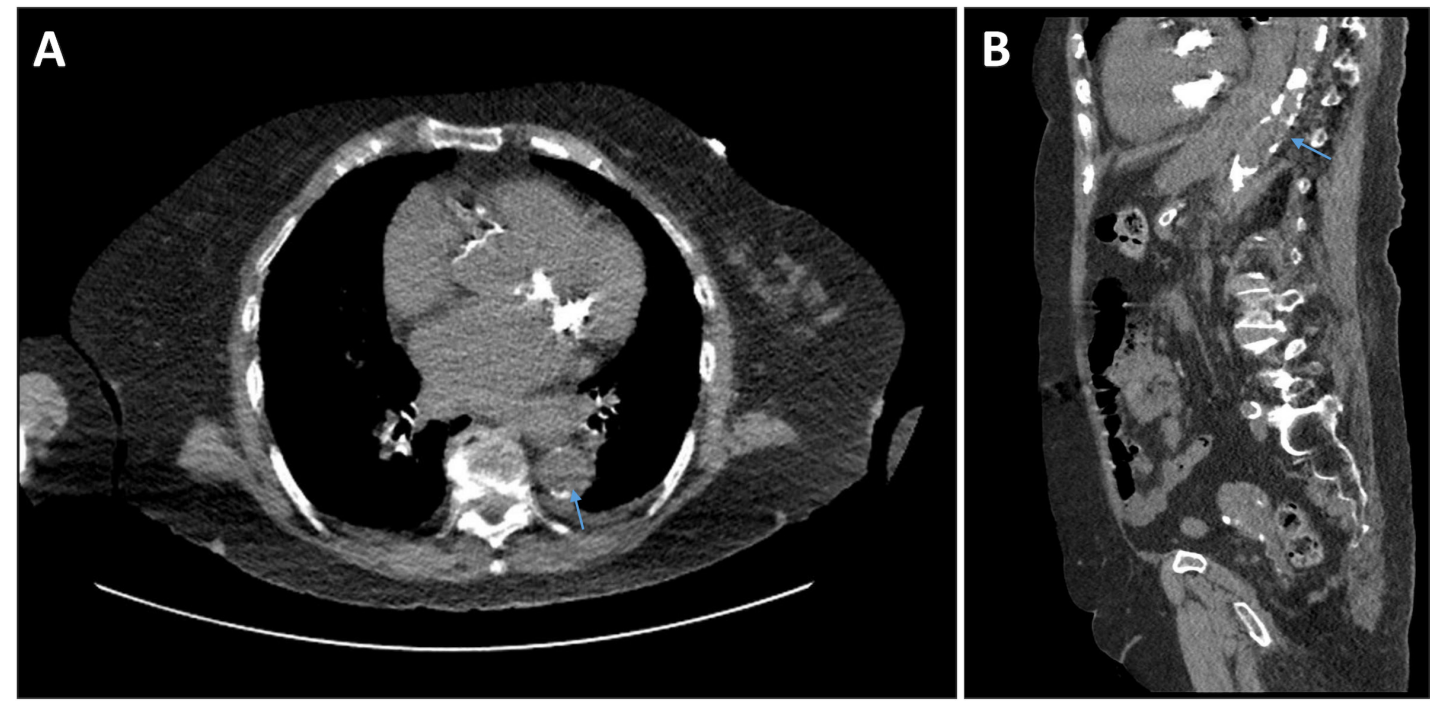

Figure $1 \mathrm{CT}$ abdomen and pelvis performed on admission with portovenous phase contrast $(\mathrm{A})$ axial image at T8 level and (B) sagittal image of a heavily atherosclerotic thoracic aorta but no surrounding collection.

\section{DESCRIPTION}

Acute aortic dissection is a clinical emergency. The most common causes are uncontrolled hypertension and atherosclerosis. ${ }^{1}$ We present a case of an acute aortic dissection diagnosed following persistent Staphylococcus aureus bacteraemia sepsis.

A 98-year-old woman was transferred to hospital after an unwitnessed fall at her aged care facility and was found to be febrile on arrival. Relevant medical history included previous stroke without significant neurologic deficit, hypertension and congestive heart failure. Medications included verapamil slow-release $240 \mathrm{mg}$ two times per day, perindopril $5 \mathrm{mg}$ in morning, indapamide $2.5 \mathrm{mg}$ in morning, frusemide $20 \mathrm{mg}$ in morning and pravastatin $20 \mathrm{mg}$ at night. She was a non-smoker and ambulated well with a four-wheel frame.

On presentation to the emergency department, she denied chest pain or presyncope. Her only localising infective symptom was a productive cough for 1 week and mild lower abdominal pain without dysuria. On examination, her blood pressure was $130 / 60 \mathrm{~mm} \mathrm{Hg}$ and heart rate 80 bpm. She had left basal inspiratory chest crepitations and mild suprapubic tenderness. There was no focal neurology. Initial inflammatory markers included C-reactive protein $324 \mathrm{mg} / \mathrm{L}$ and white cell count $12.8 \times 10^{9} /$ L. Her chest X-ray
A Check for updates

(C) BMJ Publishing Group Limited 2021. No commercial re-use. See rights and permissions. Published by BMJ.

To cite: Rehan S, Ha F, Uddin AKMN. BMJ Case Rep 2021;14:e242293. doi:10.1136/bcr-2021242293
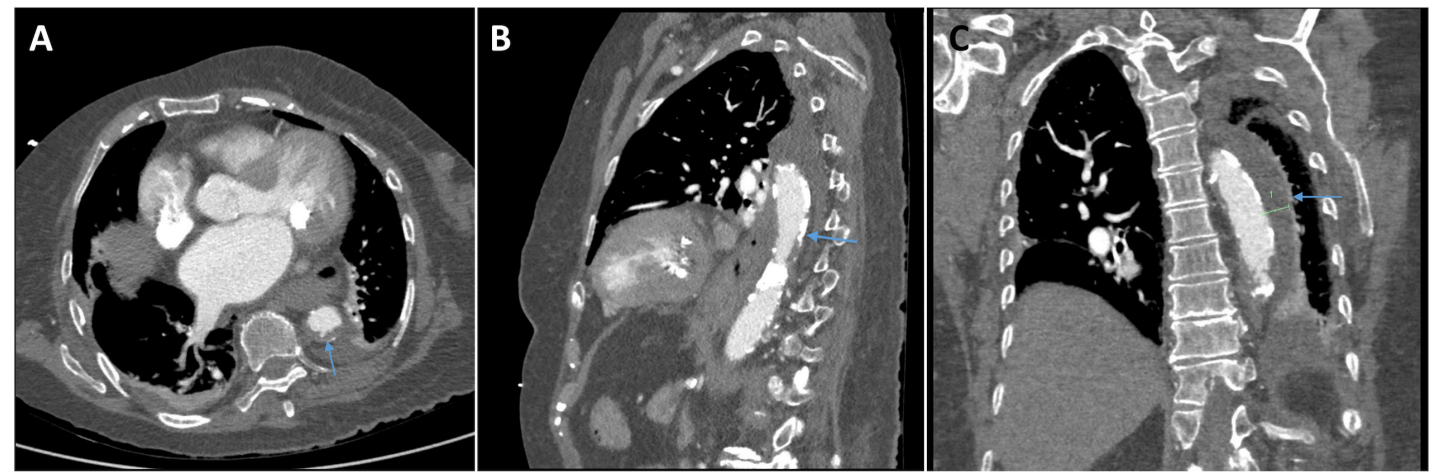

Figure 2 CT chest performed with arterial phase contrast for investigation of back pain on day 4 of admission. (A) Axial slice at the T8 level, (B) sagittal slice and (C) coronal slice demonstrated a large haematoma surrounding the descending thoracic aorta with 15 Hounsfield units. The collection appears contiguous with the posterior aortic wall. No thickening of the aortic wall or fat-stranding to suggest aortitis. 
demonstrated left lower lobe consolidation. CT abdomen and pelvis revealed no identifiable cause for her abdominal pain (figure 1). She was commenced on intravenous antibiotic therapy for community-acquired pneumonia. On day 1 of admission, blood cultures flagged positive for methicillinsensitive Staphylococcus species (MSSA) and antibiotics were rationalised appropriately. Subsequent daily blood cultures continued to grow MSSA for three further consecutive days.

On the third day of admission, the patient complained of new onset thoracolumbar back pain. She underwent a CT chest which revealed a Stanford type-B aortic dissection with a moderate haematoma surrounding the descending thoracic aorta (figure 2). This was not present on CT abdomen/pelvis performed 4 days prior. The thoracic aorta was calcified with an extensive haematoma but no active contrast extravasation to suggest ongoing bleed. In discussion with the vascular surgery team, the patient and her family, goals-of-care were shifted towards a palliative approach.

This case highlights a potential temporal relationship between sepsis and aortic dissection. Sepsis reduces vessel wall shear stress leading to microcirculatory dysfunction, loss of anticoagulation and increased local blood viscosity. ${ }^{2}$ Additionally, sepsis has been shown to increase inflammatory cytokine expression localised to the aortic lumen of mice even during its early presentation (measured at 72 hours and 120 hours) with resultant increased atheroma at 5 months follow-up. ${ }^{3}$ Existing

Learning points

- Aortic dissection is a potential sequelae of sepsis.

- Sepsis causes reduced shear stress leading to increased thrombotic, coagulopathic and inflammatory activity that could predispose to vascular intimal wall tear. atheroma (due to atherosclerosis) through intimal injury can become nidus for infection in sepsis and predisposes to aortitis. Furthermore, bacterial seeding from intimal tear can predispose to full thickness infection and ischaemia from septic emboli in vasa vasorum. ${ }^{4}$ Collectively, it appears plausible that a combination of these mechanisms could explain the endothelial damage with subsequent intimal wall tear observed in our case, exacerbated by the patient's predisposing risk factors including older age, hypertension and hypercholesterolaemia. Although our case is rare and there remains limited treatment options given her age and comorbidities, it is one of the first documented clinical examples of haemodynamic alterations in sepsis preceding an acute vascular injury.

Acknowledgements We are thankful to Dr Victor Tang, our radiologist for radiology support for all figures. We are also thankful to the Central Gippsland Health, Medicine and Radiology Department for their support.

Contributors SR is the main author of this case study and FH also contributed to finalising the case and as a senior physician AKMNU supervised the whole process and did all relevant corrections as necessary for this case study. All authors discussed the findings and contributed to the final manuscript.

Funding The authors have not declared a specific grant for this research from any funding agency in the public, commercial or not-for-profit sectors.

Competing interests None declared.

Patient consent for publication Not required.

Provenance and peer review Not commissioned; externally peer reviewed.

\section{ORCID iD}

A K M Nizam Uddin http://orcid.org/0000-0002-9836-4093

\section{REFERENCES}

1 Criado FJ. Aortic dissection: a 250-year perspective. Tex Heart Inst J 2011;38:694-700.

2 Lupu F, Kinasewitz G, Dormer K. The role of endothelial shear stress on haemodynamics, inflammation, coagulation and glycocalyx during sepsis. J Cell Mol Med 2020:24:12258-71.

3 Kaynar AM, Yende S, Zhu L, et al. Effects of intra-abdominal sepsis on atherosclerosis in mice. Crit Care 2014:18:469.

4 Lopes RJ, Almeida J, Dias PJ, et al. Infectious thoracic aortitis: a literature review. Clin Cardiol 2009;32:488-90

Copyright 2021 BMJ Publishing Group. All rights reserved. For permission to reuse any of this content visit https://www.bmj.com/company/products-services/rights-and-licensing/permissions/

BMJ Case Report Fellows may re-use this article for personal use and teaching without any further permission.

Become a Fellow of BMJ Case Reports today and you can:

- Submit as many cases as you like

- Enjoy fast sympathetic peer review and rapid publication of accepted articles

- Access all the published articles

Re-use any of the published material for personal use and teaching without further permission

Customer Service

If you have any further queries about your subscription, please contact our customer services team on +44 (0) 2071111105 or via email at support@bmj.com.

Visit casereports.bmj.com for more articles like this and to become a Fellow 